\title{
The functional and molecular studies on involvement of hydrogen sulphide in myometrial activity of non-pregnant buffaloes (Bubalus bubalis)
}

Sooraj V. Nair ${ }^{1}$, Vipin Sharma ${ }^{1}$, Abhishek Sharma', Udayraj P. Nakade ${ }^{1}$, Pooja Jaitley ${ }^{1}$, Karikalan Mathesh², Soumen Choudhury ${ }^{1}$ and Satish Kumar Garg ${ }^{1 *}$

\begin{abstract}
Background: Hydrogen sulphide $\left(\mathrm{H}_{2} \mathrm{~S}\right)$, a member of the gasotransmitters family, is known to play patho-physiological role in different body systems including during pregnancy. But its involvement in myometrial spontaneity and associated signalling pathways in uterus in non-pregnant animals is yet to be studied. Present study describes the effect of L-cysteine, an endogenous $\mathrm{H}_{2} \mathrm{~S}$ donor, on isolated myometrial strips of non-pregnant buffaloes and the underlying signaling mechanism(s).

Results: L-cysteine (10 nM-30 mM) produced concentration-dependent contractile effect on buffalo myometrium which was extracellular $\mathrm{Ca}^{2+}$ and L-type calcium channels-dependent. Significant rightward shift of dose-response curve of L-cysteine was observed with significant decrease in maxima in the presence of amino-oxyacetic acid (AOAA; $100 \mu \mathrm{M}$ ) and d, l-propargylglycine (PAG; $100 \mu \mathrm{M}$ ), the specific blockers of cystathionine $\beta$-synthase (CBS) and cystathionine $\gamma$-lyase (CSE), respectively. Existence of CBS enzyme of $63 \mathrm{kDa}$ and CSE of $45 \mathrm{kDa}$ molecular weights was confirmed by western blot using specific antibodies and also by immunohistochemistry.

Conclusions: Endogenous $\mathrm{H}_{2} \mathrm{~S}$ along with its biosynthetic enzymes (CBS and CSE) is evidently present in uteri of non-pregnant buffaloes and it regulates spontaneity in uteri of non-pregnant buffaloes and this effect is dependent on extracellular $\mathrm{Ca}^{2+}$ influx through nifedipine-sensitive L-type calcium channels. Thus $\mathrm{H}_{2} \mathrm{~S}$-signalling pathway may be a potential target to alter the uterine activities in physiology and patho-physiolgical states.
\end{abstract}

Keywords: L-type $\mathrm{Ca}^{2+}$ channel, $\mathrm{H}_{2} \mathrm{~S}$, L-Cysteine, Non-pregnant buffalo, Myometrium

\section{Background}

Hydrogen sulphide $\left(\mathrm{H}_{2} \mathrm{~S}\right)$, a well known environmental pollutant, has recently been classified as gasotransmitter along with other members (NO and $\mathrm{CO}$ ) to regulate several physiological and biological functions. Brain and certain other tissues generate $\mathrm{H}_{2} \mathrm{~S}$ from Lcysteine, the endogenous precursor which is catabolised by cystathionine $\beta$ - synthase (CBS) and cystathionine $\gamma$ -

\footnotetext{
* Correspondence: profsatish@gmail.com

${ }^{1}$ Experimental and Molecular Pharmacology Laboratory, Department of Pharmacology \& Toxicology, College of Veterinary Science and Animal Husbandry, U.P. Pandit Deen Dayal Upadhyaya Pashu Chikitsa Vigyan Vishwavidyalaya Evam Go-Anusandhan Sansthan (DUVASU), Mathura 281001, India

Full list of author information is available at the end of the article
}

lyase (CSE). Physiological importance of $\mathrm{H}_{2} \mathrm{~S}$ came into existence with the discovery of these constitutive enzymes of $\mathrm{H}_{2} \mathrm{~S}$ production and presence of nanomolar concentrations of $\mathrm{H}_{2} \mathrm{~S}$ in mammalian blood [1]. Exposure of pregnant rats to L-cysteine on gestational day 19 produced dose-dependent decrease in uterine spontaneous contractility [2]. Recently, increase in expression of CSE $(\sim 45 \mathrm{kDa})$ and CBS $(\sim 63 \mathrm{kDa})$ enzymes in rat and human myometrium during hypoxic condition [3] and dysregulated $\mathrm{CSE} / \mathrm{H}_{2} \mathrm{~S}$ signalling pathway associated with preeclampsia [4] have been reported. Present study was undertaken to decipher effect of $\mathrm{H}_{2} \mathrm{~S}$ on myometrial activity in non-pregnant buffaloes and unravel its mechanistic pathway. 


\section{Methods}

\section{Tissue collection}

Uteri along with the ovaries of non-descript buffaloes (Bubalus bubalis) were collected from the local abattoir/ butcher shop in oxygenated and chilled $\left(4.0 \pm 0.5{ }^{\circ} \mathrm{C}\right)$ Ringer Locke solution (RLS) of the composition (mM/ L)- $\mathrm{NaCl} 154, \mathrm{KCl} 5.6, \mathrm{CaCl}_{2} .2 \mathrm{H}_{2} \mathrm{O} 2.2, \mathrm{NaHCO}_{3}$ 6.0, dGlucose 5.5 and having $\mathrm{pH}$ of 7.4. Diestrous stage uteri were selected based on the well developed projected (crowned) corpus luteum on ovaries and genitalia with closed cervix and thick mucus [5]. Uteri were also cut open to rule out the possibility of early pregnancy.

\section{Functional studies}

Myometrial strips were prepared as described earlier [6]. Briefly, uterine strips were dissected out from the midcornual region and longitudinal myometrial strips $(3 \mathrm{~mm} \times$ $1 \mathrm{~cm}$ ) were prepared by carefully removing the endometrial tissues. The uterine strips were mounted in a thermostatically controlled $\left(37.0 \pm 0.5{ }^{\circ} \mathrm{C}\right)$ two channels organ bath (Ugo Basile, Italy) of $10 \mathrm{ml}$ capacity containing RLS continuously aerated with carbogen $\left(95 \% \mathrm{O}_{2}+5 \% \mathrm{CO}_{2}\right)$ under a resting tension of $2 \mathrm{~g}$. Isometric tension in myometrial strips was recorded with the help of force transducer (Panlab, Spain) using Lab Chart Pro V6.1.3 software (Powerlab, AD Instruments; Australia). During the equilibration period of $2 \mathrm{~h}$, bath fluid was changed after every $10 \mathrm{~min}$. The concentration-dependent (10 nM to $30 \mathrm{mM}$, at $0.5 \log$ dose unit) response to L-cysteine was recorded in myometrial strips.

Effect of L-cysteine alone or L-cysteine in the presence of different blockers/inhibitors was studied on two different myometrial strips prepared from the uterus of same animal. Each concentration of L-cysteine was allowed to react with the tissue for $8 \mathrm{~min}$ to construct the cumulative concentration response curve of L-cysteine alone or in the presence of either L-type $\mathrm{Ca}^{2+}$ channels blocker (nifedipine, $100 \mathrm{nM}$ ) or $\mathrm{H}_{2} \mathrm{~S}$ biosynthesizing enzyme CBS (AOAA, $100 \mu \mathrm{M}$ ) or CSE (PAG, $100 \mu \mathrm{M}$ ) inhibitors. Myometrial strips were incubated with different blockers for $30 \mathrm{~min}$ before adding L-cysteine to assess the effect of L-type $\mathrm{Ca}^{2+}$-channels blocker or enzyme inhibitors on uterotonic action of L-cysteine.

The time intervals for recording the response of $\mathrm{L}$ cysteine were selected based on the findings of our pilot experiments to record the time taken by the sub-maximal concentration of L-cysteine $\left(3 \times 10^{-5}\right)$ to produce the maximum response in myometrial strips from uteri of non-pregnant buffaloes. A time control experiment was carried out to exclude the possibility of effect of time on myometrial spontaneity during stimulation.

In a separate set of experiment, to assess the role of extracellular $\mathrm{Ca}^{2+}$, concentration-dependent response of $\mathrm{L}$-cysteine was recorded in $\mathrm{Ca}^{2+}$-free RLS. Removal of
$\mathrm{Ca}^{2+}$ from RLS resembled with the condition of lack of extracellular $\mathrm{Ca}^{2+}$ and thereby the response produced by L-cysteine seemed to be solely dependent on intracellular calcium.

Cumulative concentration-response curves were constructed using the mean integral tension (MIT) data versus concentration [7]. $\mathrm{EC}_{50}$ and $\mathrm{E}_{\max } / \mathrm{R}_{\max }$ (maximum relaxation) values were determined by non linear regression analysis using Graph Pad Prism 4.0 (GraphPad, La jolla, USA) and $\mathrm{pD}_{2}$ value (potency) was calculated as - $\log$ of $\mathrm{EC}_{50}$. Only one tissue was used from each animal and ' $n$ ' denotes the number of animals for each tension experiment.

\section{Western blot studies}

Proteins were separated on $10 \%$ SDS polyacrylamide gels using $\mathrm{GeNEi}^{\mathrm{Tm}}$ electrophoresis unit and transferred subsequently onto a polyvinylidene difluroide (PVDF) membranes at $10 \mathrm{~V}$ for $30 \mathrm{~min}$ using $\mathrm{GeNEi}^{\mathrm{TM}}$ transfer apparatus containing transfer buffer (20 mM Tris, $192 \mathrm{mM}$ glycine and $20 \%$ methanol). The membranes were then blocked in a blocking buffer containing 5\% $(w / v)$ skimmed milk powder in PBS (pH 7.4). After washing, the blots were incubated overnight at $4{ }^{\circ} \mathrm{C}$ with rabbit polyclonal $\operatorname{IgG}$ antibody to CBS (primary antibody) (sc-67,154, Santa Cruz) and rabbit polyclonal IgG antibody to CSE (primary antibody) (sc-135,203, Santa Cruz) diluted (1:200) in PBS containing $0.05 \%(v / v)$ Tween-20 (PBS-T). The blot was washed and incubated for $1 \mathrm{~h}$ at room temperature with goat anti-rabbit IgG conjugated with horseradish peroxidise (Abcam, ab6721) at 1:500 dilution in PBS-T. Immunoreactive protein was detected using DAB system $\left(\mathrm{GeNei}^{\mathrm{T} \mu}\right)$.

\section{Immunohistochemistry studies}

Buffalo myometrial sections were fixed in buffered formalin prior to processing the paraffin sections. Paraffin sections $(3 \mu \mathrm{m})$ were cut, rehydrated and microwaved in citric acid buffer to retrieve antigens. Sections were incubated with $3 \% \mathrm{H}_{2} \mathrm{O}_{2}$ in absolute methanol for $45 \mathrm{~min}$ to inhibit endogenous peroxidases, and then with $5 \%$ normal goat serum for 45 min to block the unspecific antibody binding. The specific antibodies for CSE (sc-135,203, Santa Cruz) and CBS (sc-67,154, Santa Cruz) were used both in the dilution of 1:200 in humidified chamber at $4{ }^{\circ} \mathrm{C}$ and in the control sections, slides were incubated in PBS. Then they were washed 3 times in PBS for 5 min each. Then the slides were treated with goat anti-rabbit IgG and were kept for $30 \mathrm{~min}$, and slides were rinsed thrice in PBS for 5 min each. DAB system was used for immune-labelling and DAB tablets were dissolved in $1 \mathrm{ml}$ of deionised water and working solution prepared was used. Positive reactions gave brown colour in the sections and reaction was terminated before the generalized background staining appeared in the negative control by rinsing with distilled water 
(DW). Slides were counter stained with Mayer's haematoxylin for $5 \mathrm{~min}$ and rinsed in tap water. DAB stained sections were dehydrated through graded alcohol, cleared in xylene and mounted with DPX.

\section{Chemicals}

L-cysteine, nifedipine, amino-oxyacetic acid or hydroxylamine (AOAA) and d,l-propargylglycine (PAG) were procured from Sigma-Aldrich (USA). Except nifedipine, which was dissolved in ethanol, all other chemicals were dissolved in distilled water. Stock solutions of AOAA and PAG were prepared and stored at $-20^{\circ} \mathrm{C}$. Fresh solutions of other chemicals were prepared and further dilutions were made in RLS and used on the same day of preparation. Goat anti-rabbit polyclonal antibody was obtained from Abcam while rabbit polyclonal IgG antibody to CBS (H-300) and rabbit polyclonal IgG antibody to CSE (H-167) were obtained from Santa Cruz.

\section{Statistical analysis}

Normal distribution of data was checked using D'Agostino statistical test and analysis revealed that the data of the present study were normally distributed. Results are expressed as mean \pm SEM. Concentration-dependent agonist response data were analyzed by two-way analysis of variance (ANOVA) followed by Bonferroni post-hoc test for determining the statistical differences between L-cysteine alone and in the presence of AOAA $(100 \mu \mathrm{M})$ or PAG $(100 \mu \mathrm{M})$ while Student's ' $\mathrm{t}$ ' test was applied to compare the differences between mean values of phasic versus tonic contractions, $\mathrm{E}_{\max }$ of L-cysteine alone versus L-cysteine + AOAA or Emax of L-cysteine alone versus L-cysteine + PAG. Difference in values was considered to be statistically significant at $P<0.05$. All the statistical analysis was performed using GraphPad Prism software.

\section{Results}

\section{Functional studies}

L-cysteine alone produced concentration-dependent (10 nM to $30 \mathrm{mM}$, at $0.5 \log$ dose unit) contractile effect on myometrial strips as shown in Fig. 1a and b. The maximum tension $\left(\mathrm{E}_{\max }\right)$ and potency $\left(\mathrm{pD}_{2}\right)$ were found to be $0.73 \pm 0.17 \mathrm{~g}$ and $4.71 \pm 0.28$, respectively. L-cysteine produced an increase in amplitude up to $100 \mu \mathrm{M}$ while reduction in amplitude ensued on further addition of L-cysteine. But increase in frequency was observed up to $10 \mu \mathrm{M}$. Further, compared to the effect on phasic contraction, L-cysteine significantly $(P<0.05)$ augmented the tonic contractions in buffalo myometrium (Table 1).

To elucidate the involvement of endogenous biosynthesizing enzymes in $\mathrm{H}_{2} \mathrm{~S}$ production, effect of specific enzyme blockers on L-cysteine-induced alterations
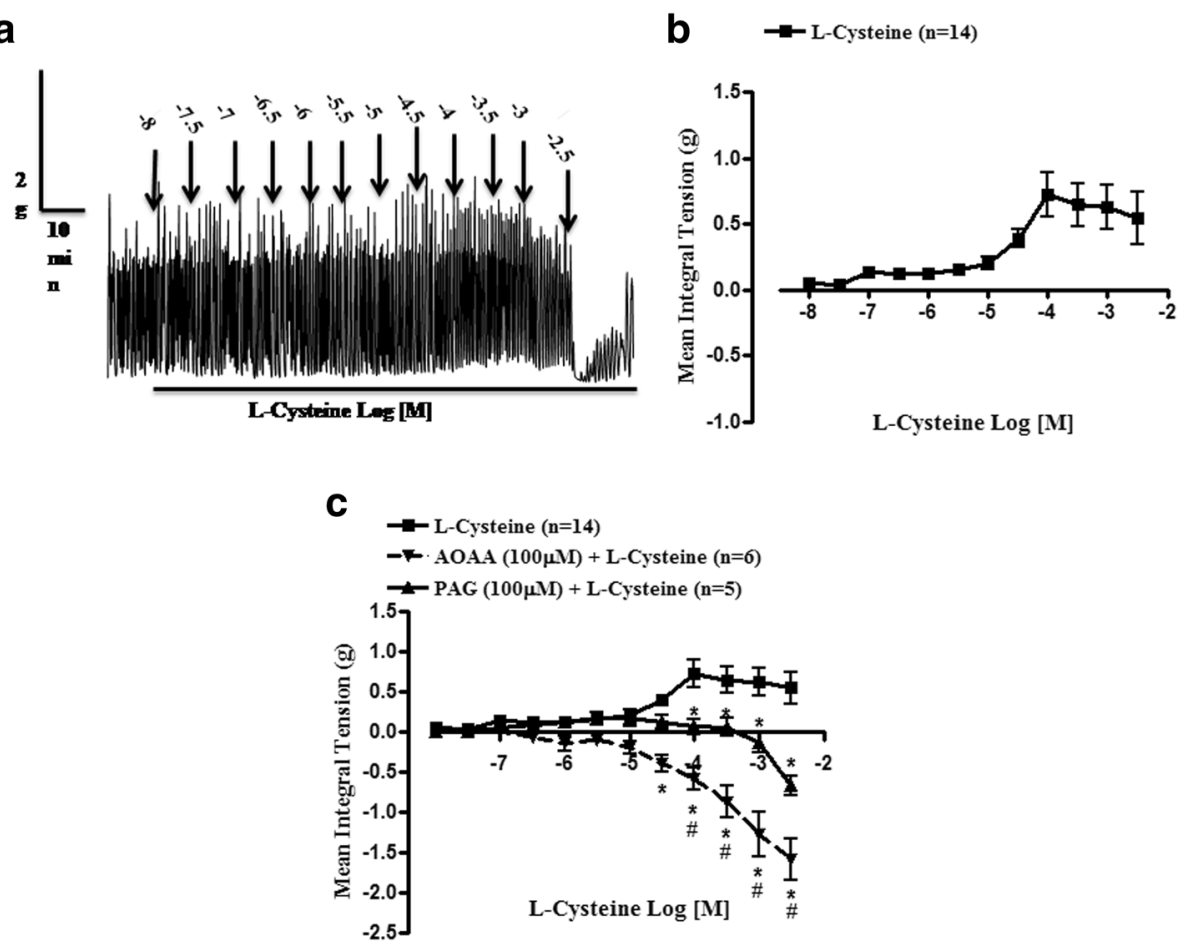

Fig. 1 Representative physiograph recording showing the concentration-dependent excitatory effect of L-cysteine (a), its cumulative dose response curve (b) and comparative cumulative concentration response curves of L-cysteine in the presence of AOAA (100 $\mu \mathrm{M})$ or PAG (100 $\mu \mathrm{M})$ on myometrial strips (c) from non-pregnant buffaloes. Vertical bars represent SEM. Data were analyzed by two-way ANOVA followed by Bonferroni post-hoc tests. * $P$ $<0.05$ L-cysteine vs. AOAA + L-cysteine or PAG + L-cysteine, ${ }^{\# P}<0.05$ PAG + L-cysteine vs. AOAA + L-cysteine 
Table 1 Effect of $L$-cysteine alone on mean integral tension ( $E_{\max }(g)$, tonic and phasic contractions $(g)$, amplitude $(g)$, frequency (BPM) and effect on MIT $(\mathrm{g})$ and in the presence of AOAA $(100 \mu \mathrm{M})$ and PAG $(100 \mu \mathrm{M})$ in myometrial strips of non-pregnant buffaloes

\begin{tabular}{lllll}
\hline Myometrial activity markers & Treatment & No. of tissues $(\mathrm{n})$ & $\mathrm{pD}_{2}$ & $\mathrm{E}_{(\max )} / \mathrm{R}_{(\mathrm{max})}(\mathrm{g})$ \\
\hline Mean Integral Tension (MIT) & L-cysteine & 14 & $4.70 \pm 0.28$ & $0.73 \pm 0.17$ \\
Phasic contraction & L-Cysteine & 6 & $4.51 \pm 0.20$ & $0.11 \pm 0.15^{*}$ \\
Tonic contraction & L-Cysteine & 6 & $4.63 \pm 0.55$ & $0.91 \pm 0.22$ \\
Amplitude & L-Cysteine & 5 & $7.09 \pm 1.75$ & $0.33 \pm 0.06$ \\
Frequency (BPM) before adding L-cysteine & L-Cysteine & 9 & $\ldots .$. & $0.80 \pm 0.09$ \\
Frequency (BPM) after adding L-cysteine & L-Cysteine & 9 & $3.42 \pm 0.83$ & $0.51 \pm 0.13$ \\
MIT & AOAA $(100 \mu M)+$ L-Cysteine & 6 & $3.64 \pm 0.163$ & $-1.54 \pm 0.26^{\$}$ \\
MIT & PAG $(100 \mu M)+$ L-Cysteine & 5 & $1.37 \pm 2.88$ & $-0.67 \pm 0.11^{\$} \#$ \\
\hline
\end{tabular}

Mean values from two different groups were compared using student's ' $t$ ' test

${ }^{*} \mathrm{P}<0.05$ Tonic contractions versus phasic contractions

${ }^{\$} \mathrm{P}<0.05$ vs. MIT of L-cysteine, ${ }^{\#} \mathrm{P}<0.05$ vs. MIT of AOAA + L-cysteine

in myometrial activity was studied. As shown in Fig. 1c, the dose response curve (DRC) of L-cysteine was significantly $(\mathrm{P}<0.05)$ shifted towards right in the presence of AOAA $(100 \mu \mathrm{M})$ and PAG $(100 \mu \mathrm{M})$ on buffalo myometrium along with significant decrease in MIT (Table 1). The $\mathrm{R}_{\max }$ and $\mathrm{pD}_{2}$ values of L-cysteine were found to be $-1.54 \pm 0.26$ and $3.64 \pm 0.16$ in presence of AOAA and $-0.67 \pm 0.11$ and $1.37 \pm 2.88$ in presence of PAG respectively (Table 1).

To elucidate the role of extracellular calcium in Lcysteine-induced uterotonic action in buffaloes, the concentration-dependent $(10 \mathrm{nM}$ to $30 \mathrm{mM}$, at $0.5 \log$ dose unit) response to L-cysteine was recorded either in the presence of nifedipine (a L-type $\mathrm{Ca}^{2+}$ channel blocker) or in $\mathrm{Ca}^{2+}$-free RLS. As shown in Fig. 2a and b, myometrial spontaneity as well as L-cysteine-induced myometrial contraction was completely abolished in the presence of nifedipine $(100 \mathrm{nM})$ as well as in $\mathrm{Ca}^{2+}$-free RLS.

\section{Western blot studies}

Western blot analysis of uterine membrane proteins revealed the presence of immune-reactive proteins to CBS $(63 \mathrm{kDa})$ and CSE $(45 \mathrm{kDa})$ enzymes in myometrium of non-pregnant buffaloes (Fig. 3).

\section{Immunochemistry studies}

Immuno-histochemistry study revealed positive immunoreactivity for CBS as well as CSE enzymes and both these enzymes were predominantly localized in the smooth muscle cells of myometrium (Fig. 4e, f) apart from positive staining of these proteins in the endometrial glands (Fig. 4b, c). Predominant positive signal from CBS (Fig. 4b, e) and weak signal for CSE (Fig. 4c, f) also support the functional involvement of $\mathrm{H}_{2} \mathrm{~S}$ in buffalo myometrium (Fig. 1c).

\section{Discussion}

Hydrogen sulphide $\left(\mathrm{H}_{2} \mathrm{~S}\right)$ is produced either by enzymatic and/or by non-enzymatic process. Among the enzymatic process, L-cysteine is considered to be the main endogenous amino acid substrate which is responsible for production of hydrogen sulphide by the action of two cytosolic enzymes, namely- CBS and CGL/CSE [8-10]. These enzymes were initially discovered in neuronal tissues [11], however, recently their existence has also been reported in rat and human myometrium $[3,12]$. Lcysteine is thought to produce its effect on cells through an excitatory amino acid transporter subtype and possibly by a zwitter ion amino acid transporter subtype (EAAT3) [13] and by a zwitter ionic amino acid transporter (ASCT1) [14]. Both these transporters are widely distributed in tissues. Once inside the cell, $\mathrm{H}_{2} \mathrm{~S}$ could be released enzymatically from L-cysteine, thus L-cysteine is considered as a direct intracellular donor of $\mathrm{H}_{2} \mathrm{~S}$ or $\mathrm{HS}^{-}$. Normally L-cysteine is transported into cells as cysteine, which then splits into two molecules of cysteine, but it is possible that L-cysteine could be transported directly when applied extracellularly [15]. On in vitro-exposure of isolated myometrial strips of buffaloes to increasing concentrations of L-cysteine ( $10 \mathrm{~nm}$ to $3 \mathrm{mM}$ ), concentration dependent uterotonic effect was observed. Rise in frequency of spontaneous contractions as well as tonic contraction by L-cysteine is also reported in non-pregnant rat and in human myometrium [15]. Intracellular concentration of L-cysteine is reported to be $30-200 \mu \mathrm{M}$ [16] with tissue levels of 10-100 $\mu \mathrm{M}$ [17]. Thus the concentrations used in the present study are well within the range of physiological concentrations of this endogenous amino acid. L-cysteine induced uterotonic action is dependent on activity of CBS and CGL/CSE as evidenced by rightward shift of the DRC of L-cysteine in the presence of enzyme blockers (AOAA or PAG). It was further observed that following blockade of CBS and CGL/CSE enzymes, 

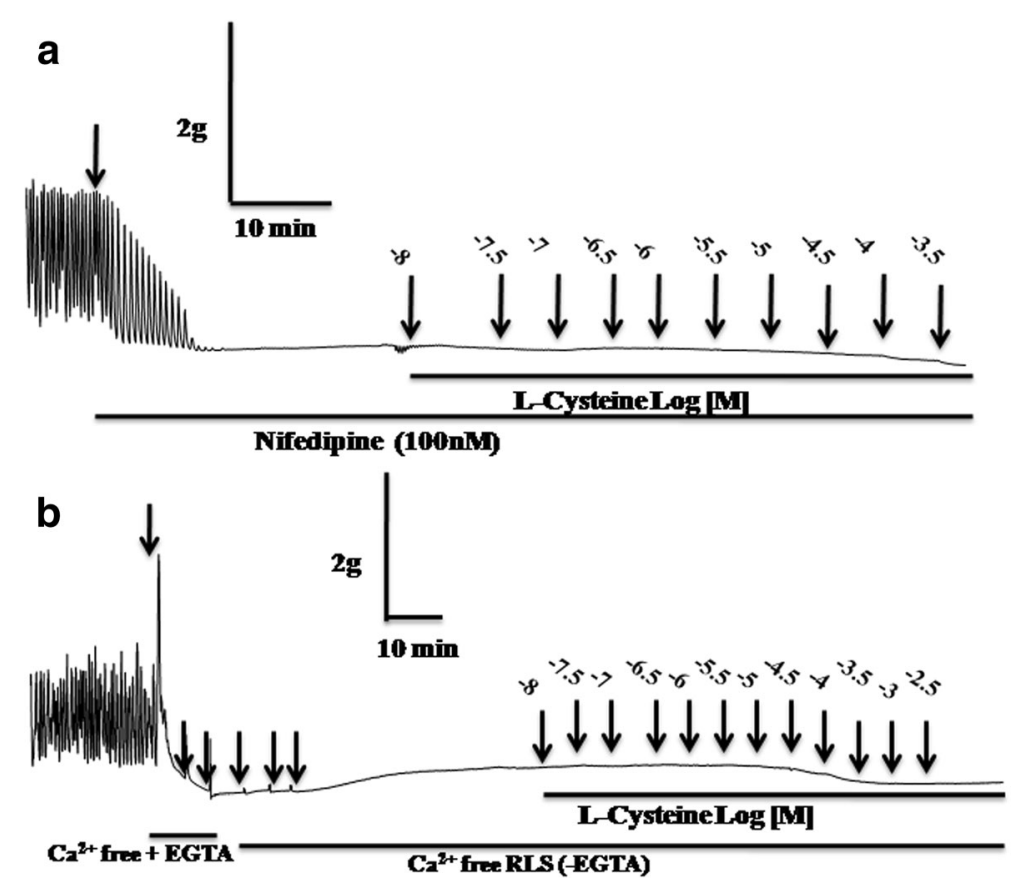

Fig. 2 Representative physiograph recording showing the effect of L-cysteine on myometrial strip of non- pregnant buffaloes in the presence of $100 \mathrm{nM}$ nifedipine $(\mathbf{a} ; n=6)$ and in $\mathrm{Ca}^{2+}$-free RLS $(n=6)$ on myometrial strips $(\mathbf{b})$ from non- pregnant buffaloes

some relaxant mechanism got activated by L-cysteine to produce uterine relaxation. Therefore, our observations evidently suggest that both these enzymes (CBS and CSE) exist in buffalo myometrium as has been reported in rat and human myometrium [3, 18]. Our assumption about the existence of these bioactivation enzymes in buffalo myometirum based on the functional studies is substantiated by our finding about the existence of CBS and CSE enzymes proteins of the molecular weights of $63 \mathrm{kDa}$ and $45 \mathrm{kDa}$, respectively, by western blot technique in

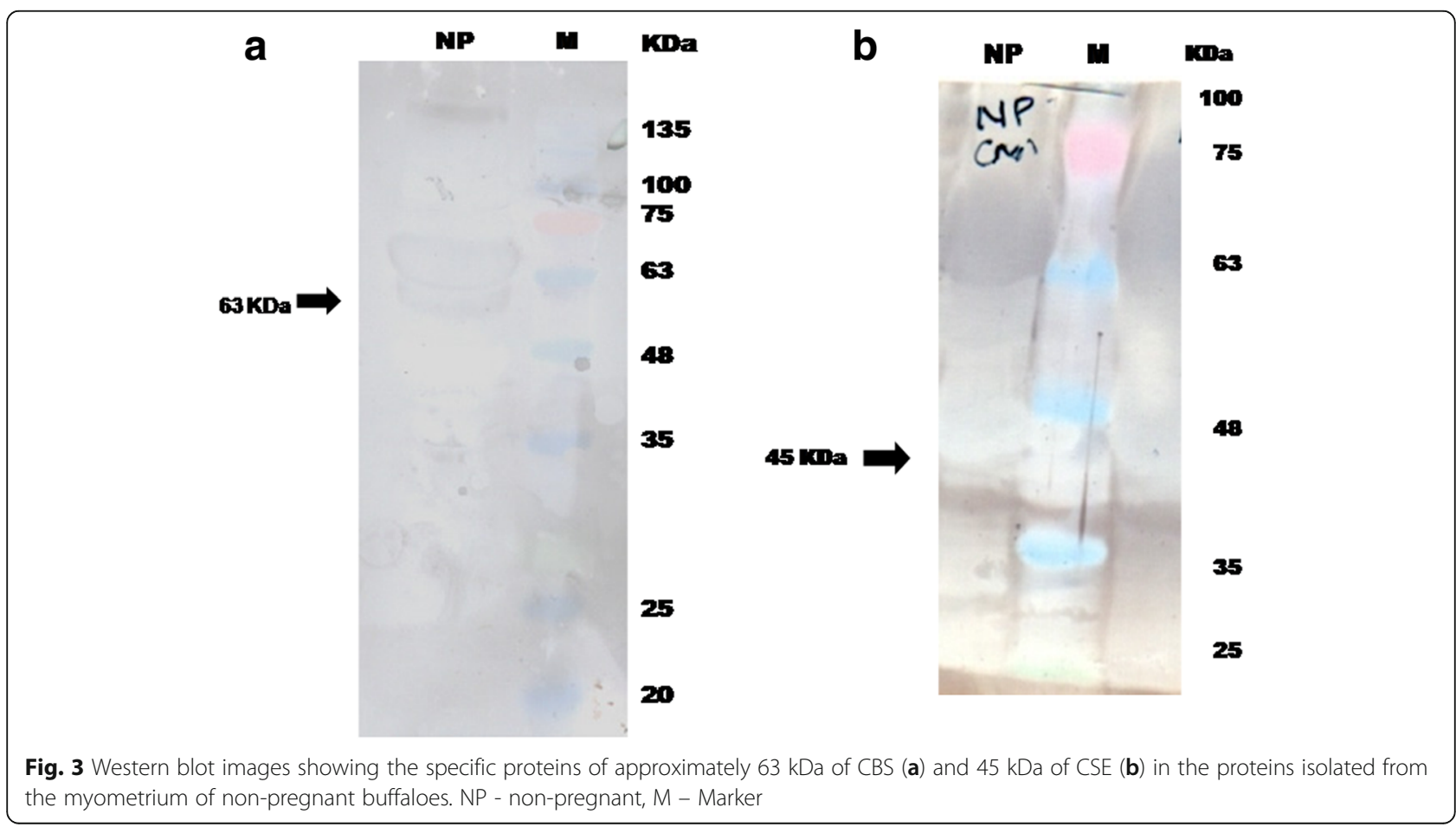




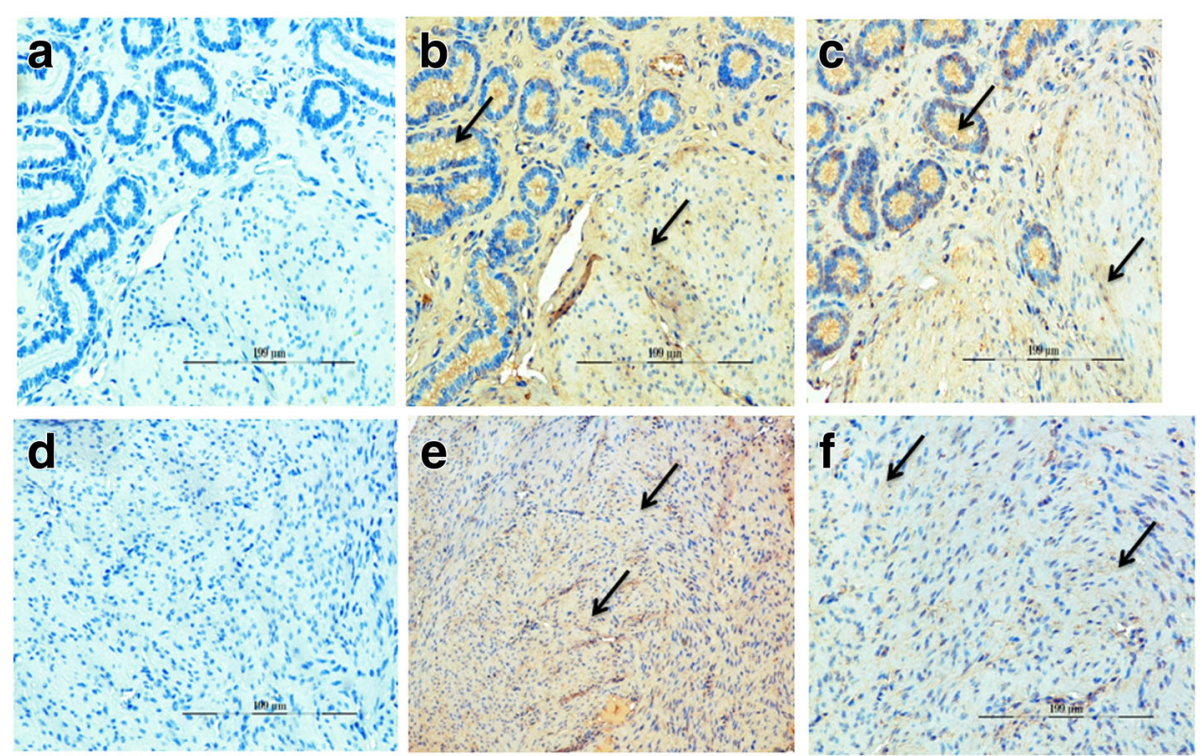

Fig. 4 Representative sections of the myometrium of non-pregnant buffaloes showing positive staining for CBS (b) and CSE (c) in endometrial glands and CBS (e) and CSE ( $f$ ) in smooth muscles of myometrium while a and $\mathbf{d}$ are negative controls. The primary antibody was substituted by normal lgG (e) and PBS (f). Arrow: positive staining in myometrium smooth muscle and its presence in endometrial glands

myometrium of non-pregnant buffaloes as reported in human myometrium [18]. The CBS enzyme was detected at $15 \mathrm{kDa}$ and at $48 \mathrm{kDa}$ in rat and human intrauterine tissues while CSE enzyme was detected at $43 \mathrm{kDa}$ in both rat and human intrauterine tissues [3]. Therefore, our findings evidently suggest about the functional importance of $\mathrm{H}_{2} \mathrm{~S}$ in regulating myometrial activity as well as molecular evidence regarding existence of $\mathrm{H}_{2} \mathrm{~S}$ producing enzymatic machinery in buffalo myometrium.

Calcium, a universal cellular regulator, is considered to be the primary signal responsible for activation of smooth muscle contractile protein [19, 20]. Cytosolic free calcium, derived from either extracellular source or intracellular pool, phosphorylates myosin light chain to induce cellular contraction. In the present study, role of calcium in L-cysteine-induced myometrial contractility is evident from the fact that following removal of calcium from extracellular fluid (RLS), myometrial spontaneity was completely abolished and this also suggests the role of extracellular calcium in generation and propagation of myometrial spontaneity in buffaloes. Our finding is in agreement with the observations of others where calcium is suggested to play an essential role in uterine myogenic spontaneity both at term [21] and during labour [22]. L-cysteine failed to produce any appreciable contraction in the absence of extracellular calcium and also in the presence of nifedipine, a L-type calcium channel blocker. Therefore, uterotonic action of Lcysteine or L-cysteine-induced myometrial contractility in non-pregnant buffaloes is completely dependent on extra cellular calcium; and nifedipine-sensitive-L-Type calcium channels play the major role as a gateway for entry of extra calcium to mediate uterotonic action of $\mathrm{H}_{2} \mathrm{~S}$. However, role of intracellular calcium cannot be completely ruled out as $\mathrm{H}_{2} \mathrm{~S}$ is reported to affect intracellular calcium mobilisation by its action on $\mathrm{IP}_{3}$ and ryanodine receptors [23, 24]. Direct inhibitory action of $\mathrm{H}_{2} \mathrm{~S}$ on calcium entry through L-type calcium channels is considered to be the underlining mechanism of its relaxant action on pregnant rat myometrium [25] and rat cardiomyocytes [26].

\section{Conclusions}

Our results suggest that L-cysteine-induced contractions in buffalo myometrium is through $\mathrm{H}_{2} \mathrm{~S}$ production and it is extracellular $\mathrm{Ca}^{2+}$-dependent and both the biosynthesizing enzymes (CBS and CSE) are present in buffalo myometrium and endogenous $\mathrm{H}_{2} \mathrm{~S}$ regulates spontaneity in myometrium of non-pregnant buffaloes. Understanding the role of endogenous gaso-transmitter mediators, especially $\mathrm{H}_{2} \mathrm{~S}$, in buffalo myometrium will help in discovery of newer drug targets for addressing the uterine disorders, especially pre-term labour and parturition in buffaloes and other species of animals.

\section{Abbreviations}

AOAA: Aminooxyacetate; CBS: Cystathionine $\beta$-synthase; CSE: Cystathionine $\gamma$-lyase; $\mathrm{H}_{2} \mathrm{~S}$ : Hydrogen sulphide; MIT: Mean integral tension; PAG: D, L-

Propargylglycine; PBS: Phosphate buffer saline; RLS: Ringer Locke solution

Acknowledgements

Not applicable. 


\section{Funding}

Financial assistance from Indian Council of Agricultural Research, New Delhi, under Niche Area of Excellence Programme (Grant No. 10(10)/2012-EPD, dated 23rd March, 2012) to Department of Pharmacology and Toxicology is thankfully acknowledged. The awarded grant is a competitive grant. Funding agency has no role in design of the study or collection, analysis, and interpretation of data and in writing the manuscript.

\section{Availability of data and materials}

The datasets used and/or analysed during the current study is available from the corresponding author on reasonable request.

\section{Ethical committee}

Committee for the Purpose of Control and Supervision of Experiments on Animals (CPCSEA).

\section{Authors' contributions}

SVN was involved in undertaking the laboratory studies, and making calculations and data analysis, and preparing the rough draft of the manuscript. VS and AS were involved in analysis and interpretation of data. PJ was involved in undertaking western blot study and interpretation of data. KM was involved in immunohistochemistry study. UPN assisted in undertaking laboratory studies and also procuring research material from the abattoir. SC and SKG were involved in the study design, supervision and guidance of the conduct of experiments analysis and interpretation of data, guiding preparation and editing of the manuscript. All authors have read and approved the final version of this manuscript.

\section{Ethics approval and consent to participate}

All the experimental protocols were followed as per the guidelines of Committee for the Purpose of Control and Supervision of Experiments on Animals (approval no. 110/IAEC/16/40/2).

\section{Consent for publication}

Not applicable.

\section{Competing interests}

The authors declare that they have no competing interests.

\section{Publisher's Note}

Springer Nature remains neutral with regard to jurisdictional claims in published maps and institutional affiliations.

\section{Author details}

${ }^{1}$ Experimental and Molecular Pharmacology Laboratory, Department of Pharmacology \& Toxicology, College of Veterinary Science and Animal Husbandry, U.P. Pandit Deen Dayal Upadhyaya Pashu Chikitsa Vigyan Vishwavidyalaya Evam Go-Anusandhan Sansthan (DUVASU), Mathura 281001, India. ${ }^{2}$ Centre for Wildlife Conservation Management and Disease Surveillance, Indian Veterinary Research Institute (ICAR-IVRI), Izatnagar, Bareilly, U.P 243 122, India.

\section{Received: 21 March 2017 Accepted: 17 November 2017}

\section{Published online: 06 December 2017}

\section{References}

1. Furne J, Saeed A, Levitt M.D. Whole tissue hydrogen sulfide concentrations are orders of magnitude lower than presently accepted values. Am J Physiol Regul Integr Comp Physiol 2008;295:1479-1485.

2. Sidhu R, Singh M, Samir G, Carson RJ. L-cystein and sodium hydrosulphide inhibit spontaneous contractility in isolated pregnant rat uterine strips in vitro. Pharmacol Toxicol. 2001:88:198-203.

3. Patel P, Vatish M, Heptinstall J, Wang R, Carson RJ. The endogenous production of hydrogen sulphide in intrauterine tissues. Reprod Biol Endocrinol. 2009;7:10.

4. Wang K, Ahmad S, Cai M, Rennie J, Fujisawa T, Crispi F, Baily J, et al. Dysregulation of the hydrogen sulfide $\left(\mathrm{H}_{2} \mathrm{~S}\right)$ producing enzyme cystathionine $y$-lyase (CSE) contributes to maternal hypertension and placental abnormalities in preeclampsia. Circulation. 2013;127:2514-22.

5. Ireland JJ, Murphee RL, Coulson PB. Accuracy of predicting stages of bovine estrous cycle by gross appearance of the corpus luteum. J Dairy Res. 1980;63:155-60
6. Choudhury S, Garg SK, Singh TU, Mishra SK. Cellular coupling of potassium channels with $\beta_{2}$-adrenoceptors in mediating myometrial relaxation in buffaloes (Bubalus Bubalis). J Vet Pharmacol Ther. 2010;33:22-7.

7. Aaronson Pl, Sarwar U, Gin S, Rockenbauch U, Connolly M, Tillet A, Watson $\mathrm{S}$, Liu B, Tribe RM. A role for voltage-gated, but not $\mathrm{Ca}^{2+}$-activated, $\mathrm{K}^{+}$ channels in regulating spontaneous contractile activity in myometrium from virgin and pregnant rats. Br J Pharmacol. 2006;147:815-24.

8. Meier M, Janosik M, Kery V, Kraus JP, Burkhard P. Structure of human cystathionine beta-synthase: a unique pyridoxal 5'-phosphate-dependent heme protein. EMBO J. 2001;20:3910-6.

9. Banerjee R, Zou CG. Redox regulation and reaction mechanism of human cystathionine- $\beta$-synthase: a PLP-dependent hemesensor protein. Arch Biochem Biophys. 2005:433:144-56.

10. Fu M, Zhang W, Wu L, Yang G, Li H, Wang R. Hydrogen sulfide (H2S) metabolism in mitochondria and its regulatory role in energy production. Proc Natl Acad Sci U S A. 2012;109:2943-8.

11. Abe $\mathrm{K}$, Kimura $\mathrm{H}$. The possible role of hydrogen sulfide as an endogenous neuromodulator. J Neurosci. 1996;16:1066-71.

12. You XJ, Xu C, JQ L, Zhu XY, Gao L, Cui XR, Li Y, Gu H, Ni X. Expression of cystathionine beta-synthase and cystathionine gamma-lyase in human pregnant myometrium and their roles in the control of uterine contractility. PLoS One. 2011;6:e23788.

13. Zerangue N, Kavanaugh MP. Interaction of L-cysteine with a human excitatory amino acid transporter. J Physiol. 1996:493:419-23.

14. Palacin M, Estevez R, Bertran J, Zorzano A. Molecular biology of mammalian plasma membrane amino acid transporters. Physiol Rev. 1998;78:969-1054.

15. Robinson, $\mathrm{H}$. Investigating the role of hydrogen sulfide in the myometrium. http://livrepository.liverpool.ac.uk/id/eprint/9493.(2013).Doctoral thesis, University of Liverpool.

16. Griffith OW. Mammalian sulfur amino acid metabolism: an overview. Methods Enzymol. 1987;143:366-76.

17. Cooper AJ. Biochemistry of sulfur-containing amino acids. Annu Rev Biochem. 1983:52:187-222

18. You XJ, Xu C, Lu JQ, Zhu XY, Gao L, Cui XR, Li Y, Gu H, Ni X. Expression of cystathionine beta-synthase and cystathionine gamma-lyase in human pregnant myometrium and their roles in the control of uterine contractility. PLoS One. 2011:6(8):e23788.

19. Fay FS, Shlem HH, Granger WC, Taylor SR. Aequorin luminescence during activation of single isolated smooth muscle cells. Nature. 1979:280:506-8.

20. Neering IR, Morgan KG. Use of aequorin to study excitation contraction coupling in mammalian smooth muscle. Nature. 1980;288:585-7.

21. Tribe RM. Regulation of human myometrial contractility during pregnancy and labour: are calcium homeostatic pathways important. Exp Physiol. 2001:86:247-54

22. Parkington HC, Tonta MA, Brennecke SP, Coleman HA. Contractile activity, membrane potential, and cytoplasmic calcium in human uterine smooth muscle in the third trimester of pregnancy and during labor. Am J Obstet Gynecol. 1999;181:1445-51.

23. Hennig B, Diener M. Actions of hydrogen sulfide on ion transport across rat distal colon. Br J Pharmacol. 2009:158:1263-75.

24. Moccia F, Bertoni G, Pla AF, Dragoni S, Pupo E, Merlino A, Mancardi D, Munaron L, Tanzi F. Hydrogen sulfide regulates intracellular $\mathrm{Ca}^{2+}$ concentration in endothelial cells from excised rat aorta. Curr Pharm Biotechnol. 2011;12:1416-26.

25. Robinson $\mathrm{H}$, Wray $\mathrm{S}$. A new slow releasing, $\mathrm{H}_{2} \mathrm{~S}$ generating compound, GYY4137 relaxes spontaneous and oxytocin-stimulated contractions of human and rat pregnant myometrium. PLoS One. 2012;7:e46278.

26. Sun WH, Liu F, Chen Y, Zhu YC. Hydrogen sulfide decreases the levels of ROS by inhibiting mitochondrial complex IV and increasing SOD activities in cardiomyocytes under ischemia/reperfusion. Biochem Biophys Res Commun 2012:421:164-9. 